\title{
DAMPAK KABUT ASAP PADA KEHIDUPAN MASYARAKAT DI KELURAHAN TUAH KARYA KECAMATAN TAMPAN KOTA PEKANBARU PROVINSI RIAU
}

\author{
Rismadani Putri \\ Program Studi Pendidikan Geografi STKIP PGRI Sumatera Barat \\ putrirismadani@gmail.com
}

\begin{abstract}
The pollution has become a very serious problem at the present time. The problem of the haze forest firest that accur on 25 agustus 2015 in Riau can also lead air pollution in village Tuah Karya district Tampan city's Pekanbaru occurance air pollution is also to disturb some sector such as : 1) Health society in the Kelurahan Tuah Karya district Tampan city's Pekanbaru province. Of Riau at the haze classified as it is not good with the rate of achievement respondents of 76,07\%, 2) Economic affairs society in the village Tuah Karya distrct Tampan city's Pekanbaru Province of Riau to income per month an average of $R p 1.000 .000-R p 1.500 .000$ with the rate of achievement 76,27\% of respondents, 3) Enviroment society in the village Tuah Karya district Tampan city's Pekanbaru Province of Riau as haze happened classified as it is not good where air quality that is not good for the people with the rate of achievement respondents $85,59 \%$ so, it can be taken the conclusion that the public health as haze influential on the condition of thepublic health, so many people who are sick like ISPA, coughing, allergies and irritation eyes. Not only health but smog also effect the social condition of the economi and environment residents where in come of a very plummeted an fall air quality also makes activities come disturbed.

Key Word: Health, Economic and the Environment
\end{abstract}

\section{PENDAHULUAN}

Pencemaran udara sudah menjadi masalah yang sangat serius pada saat sekarang ini. Masalah kabut asap kebakaran hutan yang terjadi pada tanggal Pencemaran udara sudah menjadi masalah yang sangat serius pada saat sekarang ini. Masalah kabut asap kebakaran hutan yang terjadi pada tanggal 25 agustus 2015 di Riau juga dapat memicu pencemaran udara dikelurahan Tuah Karya Kecamatan Tampan Kota Pekanbaru. Sebelum terjadinya kabut asap kondisi kesehatan masyarakat di Kelurahan Tuah Karya sangat baik serta dalam perekonomian masyarakat Tuah Karya mengalami peningkatan dilihat dalam sebulan rata-rata masyarakat memperoleh $\mathrm{Rp} 4.000 .000$ - Rp 5.000.000 dan dilihat dari lingkungan masyarakat Kelurahan Tuah Karya sangat baik.

Terjadinya Peningkatan kabut asap yang terus terjadi selama satu bulan terakhir sangat mengkhawatirkan karena kabut asap yang semakin parah dan menebal sehingga membuat jarak padang dikelurahan Tuah Karya Kecamatan Tampan Kota Pekanbaru semakin kecil. Akibatnya dampak langsung dari 
kebakaran hutan di Riau tersebut antara lain: Pertama, timbulnya penyakit infeksi saluran pernafasan akut bagi masyarakat. Kedua, berkurangnya efesiensi kerja karena saat terjadi kebakaran hutan dalam skala besar, sekolah-sekolah dan aktivitas masyarakat akan menjadi terhambat. Ketiga, terancamnya habitat asli Macan Sumatera dan Gajah karena kebakaran 25 agustus 2015 di Riau juga dapat memicu pencemaran udara dikelurahan Tuah Karya Kecamatan Tampan Kota Pekanbaru. Sebelum terjadinya kabut asap kondisi kesehatan masyarakat di Kelurahan Tuah Karya sangat baik serta dalam perekonomian masyarakat Tuah Karya mengalami peningkatan dilihat dalam sebulan rata-rata masyarakat memperoleh Rp 4.000.000 - Rp 5.000.000 dan dilihat dari lingkungan masyarakat Kelurahan Tuah Karya sangat baik.

Terjadinya Peningkatan kabut asap yang terus terjadi selama satu bulan terakhir sangat mengkhawatirkan karena kabut asap yang semakin parah dan menebal sehingga membuat jarak padang dikelurahan Tuah Karya Kecamatan Tampan Kota Pekanbaru semakin kecil. Akibatnya dampak langsung dari kebakaran hutan di Riau tersebut antara lain: Pertama, timbulnya penyakit infeksi saluran pernafasan akut bagi masyarakat. Kedua, berkurangnya efesiensi kerja karena saat terjadi kebakaran hutan dalam skala besar, sekolah-sekolah dan aktivitas masyarakat akan menjadi terhambat. Ketiga, terancamnya habitat asli Macan Sumatera dan Gajah karena kebakaran hutan juga membakar habitat mereka. Keempat, timbulnya persoalan internasional asap dari kebakaran hutan di Riau menimbulkan kerugian materiil dan imateriil di negara-negara tetangga, dan lingkungan yang menjadi tidak sehat.

Menurunnya kualitas udara di keurahan Tuah Karya Kecamatan Tampan Kota Pekanbaru tersebut ini disebabkan kebakaran hutan dan kebakaran lahan, karena penggunaan di samping itu bahan bakar fosil untuk sarana transportasi dan industri. Selain itu pencemaran udara yang di akibatkan kebakaran hutan dapat menimbulkan bau, gangguan penglihatan dan dapat menimbulkan hujan asam yang merusak lingkungan. Bencana kabut asap atau kebakaran hutan di Indonesia terjadi dalam beberapa periode, yaitu dari tahun 1982-1983, 1997-1998, 2005 hingga tahun 2010 serta periode 2011-2012, 2014 Implikasi dari bencana tersebut 
telah banyak menimbulkan kerugian baik dari sektor, perekonomian, kesehatan, lingkungan dan hubungan dengan Malaysia, Singapura, dan negara ASEAN lainnya.

Awal terjadinya kebakaran hutan dalam jumlah yang besar terjadi pada tahun 1982-1983. Periode ini kebakaran hutan terjadi diaerah Kalimantan Timur yang telah menghabiskan lahan sebanyak $210.000 \mathrm{~km} 2$ dari seluruh daerah provinsi Kalimantan Timur dari kejadian tersebut banyak menimbulkan kerugian seperti dari segi kesehatan dimana banyak masyarakat yang terkena ISPA, alergi baruk-batuk dan iritasi mata. Dilihat dari perekonomian saat kabut asap terjadi perekonomian warga menjadi berkurag bisa dilihat dari segi pnjualan warga yang mulai menurun di akibatkan berkurangnya pembeli yang di akibatkan tebalnya kabut asap membuat warga takut untuk keluar rumah, Sedangkan dilihat dari segi lingkungan kabut asap yang tebal membuat udara dan kelancaran aktivitas warga menjadi terganggu.

Dua faktor utama yang menyebabkan kebakaran hebat tersebut terjadi yaitu kebijakan pengelolaan hutan pada masa Presiden Soeharto dan terjadinya fenomen iklim El-Nino. Hal tersebut tergambar dari meningkatnya ledakan produksi kayu di Indonesia dan kebijakan pemerintah yang menjadikan hampir seluruh kawasan dijadikan sebagai HPH (Hak Penguasaan Hutan) menurut Rahmi Jurnal Transnasional, (Vol. 7, No. 1, Juli 2015), dan samapai tahun 2015 kabut asap juga melanda kota pekan baru sehingga membuat jarak pandang hanaya pmencapai 100 meter serta lahan yang terbakar pun mencapai $2.430 \mathrm{Ha}$.

Hutan yang merupakan sumberdaya alam yang tidak ternilai karena didalamnya terkandung keanekaragaman hayati sebagai sumber plasma nutfah, sumber hasil hutan kayu dan non-kayu, pengatur tata air, pencegah banjir dan erosi serta kesuburan tanah, perlindungan alam hayati untuk kepentingan ilmu pengetahuan, kebudayaan, rekreasi, pariwisata dan sebagainya, karena itu pemanfaatan hutan dan perlindungannya telah diatur dalam UUD 45. Namun adapun UUD 45 yang telah di berlakukan tetapi masyarakat kadang tidak jera untuk membakar hutan dan menebang hutan secara liar. 
Terjadinya kebakaran hutan dapat mengakibatkan pencemaran udara yang bersifat lintas batas, Kebakaran hutan yang terjadi di Riau juga dapat disebabkan oleh 2 hal, penyebabnya kebakaran hutan tersebut yakni: pertama Kebakaran hutan yang disebabkan oleh alam (1) Gejala alam skala global merupakan kondisi alam yang tidak mendukung, misalnya, bencana alam, musim kemarau panjang yang membuat areal kehutanan menjadi panas. (2) Lahan gambut dapat menjadi bahan bakar yang relative melimpah sebab kekeringan telah menyebabkan air tanah menurun di rawa-rawa air tanah yang besar di pedalaman. Lantas lapisan gambut terpapar dan mengering. Pohon yang kebanyakan yang memiliki perakaran dangkal mengering dan tumabang baik gambut kering maupun kayu mati akhirnya merupakan bahan bakar yang efektif bagi penyebaran api pada permukaan dan di atas tanah. Kedua Kebakaran hutan yang disebabkan oleh manusia. (1) Ahli fungsi hutan / pembukaan lahan untuk perkebunan, pertanian, pemukiman, transmigrasi dengan menggunakan api yang tidak terkendali. Ini merupakan penyebab utama dari kebakaran hutan yang terjadi di Indonesia. (2) Illegal logging yang dilakukan oleh pengusaha-pengusaha yang tidak bertanggung jawab merupakan salah satu penyebabkan kebakaran hutan. Karena sisa-sisa penebagan hutan tersebut dapat menjadi salah satu bahan bakar potensial yang memperpanjang usia kebakaran hutan yang terjadi.

\section{METODOLOGI}

Penelitian ini tergolong pada jenis penelitian Deskrptif. Penelitian deskriptif yaitu penelitian yang bertujuan untuk mendekripsikan, menggambarkan dan menganalisa kejadian yang ada serta bertujuan untuk memperoleh informasiinformasi mengenai dampak kabut asap di Kecamatan Tampan Kota Pekanbaru dengan teori yang ada. Penelitian deskriptif menurut Nawawi (2012:67) adalah metode penelitian deskriptif dapat diartikan sebagai prosedur pemecahan masalah yang diselidiki dengan menggambarkan/ melukiskan keadaan subyek/ obyek penelitian (seseorang, lembaga, masyarakat dan lain-lain) pada saat sekarang berdasarkan fakta-fakta yang tampak, atau sebagaimana adanya.

Teknik analisa data yang digunakan untuk menganalisa data penelitian ini adalah secara deskriptif yaitu digunakan analisa statistik berupa formula 
persentase karena tujuannya adalah untuk melihat kecendrungankecendrungan indikator masing-masing variabel dan penelitian ini hanya bertujuan untuk menggambarkan kenyataan dilapangan tidak untuk dilihat hubungan atau perbandingan oleh sebab itu maka rumus persentase sangat cocok dalam penelitian ini dengan rumus:

Dimana :

$P=f / n \times 100 \%$

$\mathrm{P}$ : Persentase

$\mathrm{F}:$ Frekuensi

$\mathrm{n}:$ Jumlah responden

(Sumber : Arikunto suharsimi :2006)

\section{PEMBAHASAN}

Berdasarkan hasil penelitian, diperoleh gambaran sebagai berikut:

Kesehatan masyarakat di Kelurahan Tuah Karya Kecamatan Tampan Kota Pekanbaru pada saat kabut asap terjadi sangat mempengaruhi kodisi kesehatan jasmani dimana terganggunya fungsi mekanisme tubuh sehingga warga Tuah Karya murah terserang penyakit contohnya seperti ISPA, alergi, batuk-batu dan iritasi mata, tidak hanya kesehatan jasmani yang terganggu tetapi kenyamanan warga juga ikut terganggu banyak warga yang mengeluh akibat kabut asap. Sedangkan dilihat dari tingkat sosial warga sangat kurang karena kebanyakan warga yang acuh tak acuh dengan warga lainnya saat kabut asap terjadi, dan jarak yang harus di tempuh warga untuk pergi berobat juga sangat jauh yaitu sekitar 5 kilo dari rumah warga.

Penelitian ini sesuai dengan penelitian Yulaswita (2013) dimana dalam penelitian Yulaswita mengatakan kesehatan jasmani merupakan dimensi sehat yang paling nyata yaitu fungsi mekanisme tubuh. Sedangkan Kesehatan rohani (kenyamanan/kejiwaan) yaitu perasaan sehat dan bahagia serta mampu mengatasi tantangan hidup, dapat menerima orang lain sebagaimana adanya serta mempunyai sikap positif terhadap diri sendiri. Dalam penelitian ini sangat terkait karna selama kabut asap terjadi mekanisme tubuh warga sangat terganggu dan kenyamanan warga juga ikut terganggu. 
Pendapatan warga Tuah Karya yang terkena dampak kabut asap untuk pendapatan pokok/bulan yang mereka memperoleh hanya yaitu Rp 1.000 .000 Rp 1.500.000/bulan, sedangkan pendapata perminggu rata-rata mereka hanya mendapatkan Rp. 500.000 - Rp. 700.000 Selama kabut asap terjadi. Berbeda dengan Sebelum terjadinya kabut asap dimana pendapatan warga Tuah Karya lebih besar dibandingkan saat kabut asap terjadi bisa dilihat pendapatan perbulan sebelum terjadinya kabut asap mereka rata-rata berkisar $\mathrm{Rp} 4.000 .000$ - Rp 5.000.000/bulan, sedangkan pendapatan rata-rata warga Tuah Karya Rp 500.000 dan pendapatan dari pekerjaan sampingan warga rata-rata memperoleh $\mathrm{Rp}$ 1.500 .000 - Rp 2.000.000.

Penelitian ini sesuai dengan pendapat Noor (2007:186) diamana Noor mengatakan pendapatan ini dapat di kelompokkan menjadi beberapa jenis yaitu: Pendapatan pokok adalah jumlah seluruh pendapatan dari penjualan, sedangkan Pendapatan rata-rata yaitu pendapatan rata-rata dari setiap unit penjualan dan Pendapatan tambahan yaitu tambahan pendapatan yang didapat untuk setiap tambahan satu unit penjualan.

Pengaruh kabut asap terhadap kualitas udara saat kabut asap terjadi sangat buruk dikarenkan kabut asap yang tebal membuat kondisi lingkungan warga menjadi tidak terkendali dan jarak pandang pun bisa dikatakan hanya $100 \mathrm{~m}$, tidak hanya kulitas udaratetapi dampak kabut asap juga sangat berpengaruh terhadap tanaman dimana akibat dampak kabut asap tanaman banyak yang mrnjadi layu dan mati sehingga membuat warga menjadi rugi, dan pengaruh kabut asap juga berpengaruh terhadap kelancaran transportasi dimana banyaknya angkot yang tidak jalan akibat kabut asap, dank abut asap juga menganggu aktivitas warga.

Penelitian ini sesuai dengan Melda Mardani (2013) yaitu: Lingkungan fisik, yaitu lingkungan yang dari gaya kosmik dan fisiografis seperti tanah, udara, laut, radiasi, gaya tarik, ombak dan sebagainya, seadangkan Lingkungan social ini dapat dibagi kedalam tiga bagian : pertama Lingkungan fisiososial, yaitu yang meliputi kebudayaan materil, kedua Lingkungan biososial manusia dan bukan manusia, yaitu manusia dan interaksinya terhadap sesamanya dan tumbuhan beserta hewan domestic dan semua bahan yang digunakan manusia yang berasal 
dari sumber organic. Ketiga Lingkungan psikososial, yang berhubungan dengan tabiat batin manusia seperti sikap, pandangan, keinginan, kayakinan.

\section{KESIMPULAN}

Dari hasil penelitian mengenai dampak kabut asap pada masyarakat di Kelurhan Tuah Karya Kecamatan Tampan Kota Pekanbaru Provinsi Riau dapat diambil kesimpulan sebagai berikut :

1. Kesehatan di Kelurahan Tuah Karya Kecamatan Tampan Kota Pekanbaru pada saat kabut asap terjadi memang sangat berdampak terhadap kodisi kesehatan jasmani seperti penyakit ISPA, alergi, batuk-batuk dan iritasi mata, tidak hanya kesehatan jasmani tetapi kenyamanan warga jg ikut terganggu saat terjadinya kabut asap. Sedangkan dilihat dari tingkat sosial warga sangat kurang karena kebanyakan warga yang acuh tak acuh dengan warga lainnya saat kabut asap terjadi, dan jarak yang harus di tempuh warga untuk pergi berobat juga sangat jauh yaitu sekitar 5 kilo dari rumah warga.

2. Pendapatan di Kelurahan Tuah Karya Kecamatan Tampan Kota Pekanbaru pada saat terjadi memang sangat berpengaruh terhadap pendapatan warga Tuah Karya dimana pendapatan pokok/bulan yang mereka memperoleh ratarata $\mathrm{Rp} 1.000 .000-\mathrm{Rp}$ 1.500.000/bulan, sedangkan pendapata perminggu rata-rata mereka hanya mendapatkan Rp. 500.000 - Rp. 700.000 Selama kabut asap terjadi. Berbeda dengan Sebelum terjadinya kabut asap dimana pendapatan warga Tuah Karya lebih besar dibandingkan saat kabut asap. terjadi bisa dilihat pendapatan perbulan sebelum terjadinya kabut asap mereka rata-rata berkisar Rp 4.000.000 - Rp 5.000.000/bulan, sedangkan pendapatan rata-rata warga Tuah Karya $\mathrm{Rp} 500.000$ dan pendapatan dari pekerjaan sampingan warga rata-rata memperoleh Rp 1.500.000 - Rp 2.000.000.

3. Lingkungan warga Tuah Karya Kecamatan Tampan Kota Pekanbaru Provinsi Riau bahwa dampak kabut asap terhadap lingkungan fisik dan sosial sangat berpengaruh terhadap kualitas udara dikarenkan kabut asap yang tebal membuat kondisi lingkungan warga menjadi tidak terkendali dan jarak pandang pun bisa dikatakan hanya $100 \mathrm{~m}$, tidak hanya kulitas udara tetapi dampak kabut asap juga sangat berpengaruh terhadap tanaman dimana akibat dampak kabut asap tanaman banyak yang mrnjadi layu dan mati sehingga membuat warga menjadi rugi, dan pengaruh kabut asap juga berpengaruh terhadap kelancaran transportasi dimana banyaknya angkot yang tidak jalan akibat kabut asap dan pemasuakan warga pun menjadi 
berkurang, dan kabut asap juga membuat aktivitas warga terganggu sehingga banyak warga yang hanya berdiam diri dirumah selama kabut asap terjadi.

\section{DAFTAR PUSTAKA}

Arikunto, Suharsimi. 2006. Manajemen Penelitian. Jakarta: PT RINEKA CIPTA.

Mardani,Mela. 2013. Konsi Sosial Ekonomi dan Lingkungan Masyarakat Sebelum Dan sesudah Pembangunan Pasir di Nagari Talaok Kecamatan Bayang Kabupaten Pesisir Selatan. Skripsi. STKIP PGRI Sumatera Barat

Nawawi, Hadari. 2012. Metode Penelitian Bidang Sosial, Yogyakarta: Gadjah Mada University.

Noor. 2007. Standar Akutansi Keuangan. Medan: FE Universitas Sumatera Utara.

Yulaswita,Rezi. 2013. Studi Tingkat Kesejahteraan Pemulung Batu Bara di Kecamatan Talawi Kota Sawahlunto. Skripsi. STKIP PGRI Sumatera Barat. 